\title{
The Biological Effects of IL-21 Signaling on B-Cell-Mediated Responses in Organ Transplantation
}

\author{
Yongkang $W_{u^{1,2}}$, Nicole M. van Besouw2 ${ }^{2}$, Yunying Shi3 ${ }^{3}$, Martin J. Hoogduijn ${ }^{2}$, \\ Lanlan Wang ${ }^{1}$ and Carla C. Baan ${ }^{2 *}$
}

${ }^{1}$ Department of Laboratory Medicine, West China Hospital, Sichuan University, Chengdu, China, ${ }^{2}$ Sector Nephrology \& Transplantation, Department of Internal Medicine, Erasmus MC, University Medical Center Rotterdam, Rotterdam, Netherlands, ${ }^{3}$ Department of Nephrology, West China Hospital, Sichuan University, Chengdu, China

\section{OPEN ACCESS}

Edited by: Brian Duncan Tait, Australian Red Cross Blood Service, Australia

Reviewed by: Alexandre Corthay, University of Oslo, Norway Federica Casiraghi, Mario Negri Institute for Pharmacological Research, Italy

${ }^{*}$ Correspondence: Carla C. Baan c.c.baan@erasmusmc.n

Specialty section: This article was submitted to Alloimmunity and Transplantation,

a section of the journal

Frontiers in Immunology

Received: 13 June 2016 Accepted: 08 August 2016 Published: 23 August 2016

Citation:

Wu Y, van Besouw NM, Shi Y, Hoogduijn MJ, Wang $L$ and Baan CC (2016) The Biological Effects of IL-21

Signaling on B-Cell-Mediated Responses in Organ Transplantation.

Front. Immunol. 7:319. doi: 10.3389/fimmu.2016.00319
Antibody-mediated rejection has emerged as one of the major issues limiting the success of organ transplantation. It exerts a highly negative impact on graft function and outcome, and effective treatment is lacking. The triggers for antibody development, and the mechanisms leading to graft dysfunction and failure, are incompletely understood. The production of antibodies is dependent on instructions from various immunocytes including CD4 T-helper cells that secrete interleukin (IL)-21 and interact with antigen-specific B-cells via costimulatory molecules. In this article, we discuss the role of IL-21 in the activation and differentiation of B-cells and consider the mechanisms of IL-21 and B-cell interaction. An improved understanding of the biological mechanisms involved in antibody-mediated complications after organ transplantation could lead to the development of novel therapeutic strategies, which control humoral alloreactivity, potentially preventing and treating graft-threatening antibody-mediated rejection.

Keywords: IL-21, IL-21 receptor, JAK/STAT, B-cell, organ transplantation, rejection

\section{INTRODUCTION}

Antibody-mediated rejection remains an important barrier to improving long-term survival after solid organ transplantation (1-3). In cellular rejection, graft injury is due to direct cytotoxic activity of immune cells against graft parenchymal tissue. Antibody-mediated rejection, in contrast, is characterized by graft damage induced by circulating alloantibodies. Alloantibodies are produced by activated B-cells in response to antigen, costimulation, and cytokines such as interleukin (IL)-21 $(4,5)$.

Interleukin-21 was discovered by Parrish-Novak et al. using a functional cloning approach based on expression of the IL-21 receptor (IL-21R) gene and is located at chromosome 4 on position q26-q27 (6). The common $\gamma$-chain $(\gamma c)$ is a component of the IL-21R complex. IL-21 binding to the IL-21R/ $\gamma c$ results in signaling via the JAK/STAT pathway $(6,7)$. This cytokine, a four- $\alpha$-helix bundle,

\footnotetext{
Abbreviations: AID, activation-induced cytidine deaminase; BAFF, B-cell activating factor; BCL-6, B-cell lymphoma-6; Blimp1, B lymphocyte-induced maturation protein-1; BMPs, bone morphogenetic proteins; Btk, Bruton's tyrosine kinase; BTB, also named POZ, pox virus and zinc finger; CpG, 5'-C-phosphate-G-3'; CSR, class switch recombination; GrB, granzyme B-cell; Ig, immunoglobulin; IL-21, interleukin-21; IL-21R, IL-21 receptor; LPS, lipopolysaccharide; mAb, monoclonal antibody; RD2, the second repression domain; Th, follicular T helper cells; TLO, tertiary lymphoid organ; TLR, toll-like receptor; XBP-1, $\mathrm{X}$-box-binding protein-1; $\gamma \mathrm{c}$, common $\gamma$ chain.
} 
is a typical family I cytokine with broad pleiotropic actions and is primarily produced by $\mathrm{T}$ follicular helper cells (Tfh), Th17, and natural killer T-cells, rather than being generally produced by most tissue cells $(6,8,9)$. IL-21 controls the activation, proliferation, differentiation, cytotoxicity, and survival of various target immune cells $(10,11)$. It is also important for the generation of $\mathrm{B}$-cell responses in germinal centers resulting in isotype switching, affinity maturation, antibody production, and development of B-cells $(12,13)$. In particular, IL-21-mediated actions by Tfh cells are required for efficient antibody responses. The effectors and immune regulatory functions of IL- 21 are mediated by binding to target B-cell surface receptors, which consist of $\alpha$-chain and the $\gamma c$ that is shared with IL-2, IL-4, IL-7, IL-9, and IL-15 receptors $(10,14,15)$.

Antibody-mediated ("humoral") rejection is a key cause of graft dysfunction and failure after organ transplantation $(1,16,17)$ with $30-50 \%$ of failed allografts affected $(18-20)$. Immunohistochemical and gene expression studies have shown that a large number of B-cells infiltrate the rejected allograft (18, 21-24), contributing to anti-donor responses.

Identifying the role of IL-21-mediated B-cell activation and differentiation pathways is critical for understanding the signaling pathways that underlie antibody-mediated rejection. In this review, we discuss the potential role of IL-21 on B-cells after organ transplantation.

\section{IL-21 SIGNALING PATHWAY IN B-CELLS}

The IL-21R is expressed by human naive B-cells, memory B-cells, germinal center B-cells (14), and as shown recently, plasma cells (25). IL-21R is upregulated on human memory B-cells after activation by anti-CD40 $\mathrm{mAb}(14)$.
Binding of IL-21 with IL-21R/ $\gamma$ c triggers the catalytic activation of JAK1 and JAK3. This causes phosphorylation of tyrosine residues on IL-21R/ $\gamma \mathrm{c}$, providing docking sites for STAT proteins and other signaling molecules (26). On recruitment, STATs are phosphorylated and form homodimers or heterodimers, which translocate into the nucleus and modulate expression of the target genes (27), which regulate B-cells, such as B-cell-induced maturation protein-1 (Blimp-1) (28), B-cell lymphoma (BCL)-6 (29), activation-induced cytidine deaminase (AID) (30), granzyme (31), somatic hypermutation (SHM) (32), paired box 5 (Pax5) (33), X-box-binding protein 1 (XBP-1) (34), and Bim (35). IL-21 mediates B-cell proliferation, immunoglobulin (Ig) production, and apoptotic functions mainly through the potent effects of STAT3 and/or STAT1 activation but also, to a lesser extent, through STAT4 and STAT5 (36-39) (Figure 1).

\section{B-CELL ACTIVATION AND DIFFERENTIATION}

B-cell receptor (BCR) ligation triggers activation of multiple downstream molecules. Burton's tyrosine kinase (Btk), one of the downstream products of the BCR signaling pathway, selectively regulates IL-21-induced STAT1 phosphorylation and translocation in the nucleus. Btk deficiency is associated with arrested cell development at the pre-B-cell stage. In addition, Btk is involved in cytokine-controlled B cell activation. In concert with IL-21, CD40, and B-cell activating factor (BAFF), this kinase mediates the crosstalk with cytokine pathways through regulation of IL-21induced phosphorylation of STAT1 (25). IL-21 and CD40L collaborate to synergistically promote Blimp-1 activation and plasma cell differentiation (28). CD40L alone has no direct effect on Blimp-1, but it greatly augments the IL-21-triggered JAK-STAT

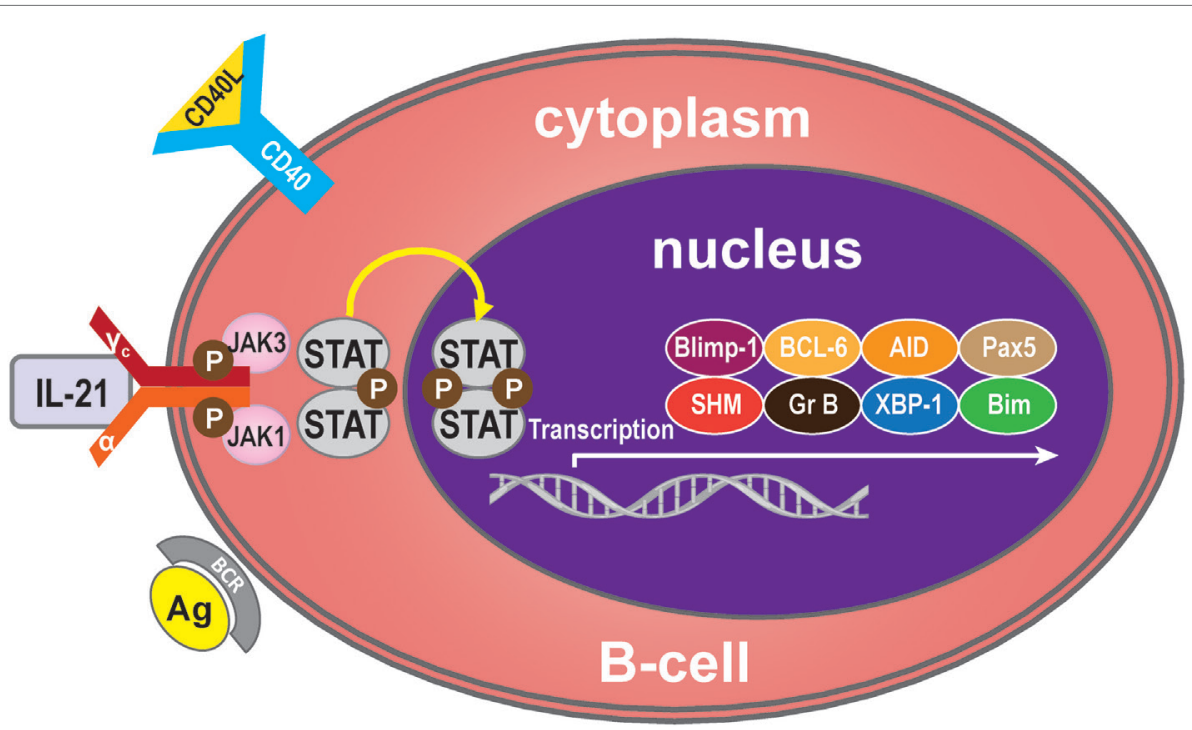

FIGURE 1 | IL-21 signaling pathway. Many molecules participate in the IL-21 signaling pathway in B-cells, but the main molecules are IL-21R, JAK, and STAT to activate transcription of Blimp-1, BCL-6, AID, Pax5, SHM, granzyme B, XBP-1, and Bim. Generally, IL-21 binds with the IL-21R of B-cells to trigger signaling pathways. The JAK and STAT family molecules are activated in turn, while the balance of the transcription factors Blimp-1 and BCL-6 control the maturation B-cell. 
signaling. During this phase, STAT3 plays a more significant role than STAT1, because STAT3 mutations dramatically reduce the number of memory B-cells and abolish the ability of differentiation of naive B-cells into plasma cells (10). In contrast, STAT1 deficiency has no effect on memory B-cell formation in vivo. Thus, STAT3 is essential for the generation of effector memory B-cells from naive precursors (40). In addition, treatment with CD40L enhances the ability of STAT3 to upregulate Blimp-1 by removing BCL-6, which is a potent inhibitor of Blimp-1 expression. It has been speculated that IL-21 induces Blimp-1 and BCL- 6 to regulate isotype-switched B-cells (41). Blimp-1 is a transcription factor and involved in plasma cell formation and maturation (42). Importantly, IL-21 costimulation upregulates expression of Blimp-1 (43). Consistent with this, IL-21-driven plasma cell differentiation from both naive blood B-cells and from memory B-cells are preceded by induction of Blimp-1 upregulation. Blimp-1 initiates plasma cell differentiation by downregulating MHC, CIITA, Pax5, and c-myc expression (33, $44,45)$ and by inducing XBP-1 expression $(46,47)$. Blimp- 1 level is very low when BCL-6 is over-expressed in B-cells (48). BCL-6 may block plasma cell differentiation due to downregulation of Blimp-1 (49). BCL-6 also can control B-cell development by BTB and RD2, two molecules that repress distinct functional effects of $\mathrm{B}$-cells during the germinal centers reaction. BTB is required for B-cell survival and proliferation, while RD2 might be important for the prevention of terminal B-cell differentiation (50).
Since IL-21 activates STAT3 in B-cells, this may indicate that activation of STAT3 in human B-cells is pivotal for the induction of Blimp-1 expression and plasma cell differentiation $(11,40)$. It has been reported that IL-21-dependent CD86 upregulation is reliant on STAT3 phosphorylation and $\mathrm{PI} 3 \mathrm{~K}$, revealing unexpected roles for these pathways in IL-21-mediated B-cell responses (51). In addition, IL-21 drives humoral immune responses via STAT3dependent induction of the transcription factors required for plasma cell generation (52). These authors reported that IL-21 via STAT3 sensitizes B-cells to the stimulatory effects of IL-2. Thus, IL-2 plays an adjunctive role in IL-21-induced B-cell differentiation. An absence of this secondary effect of IL-21 may amplify humoral immunodeficiency in patients with mutations in STAT3 and IL-21R due to impaired responsiveness to IL-21. In concert, IL-21 and BAFF stimulate and may maintain humoral immunity in humans (53). BAFF has the ability to substitute for CD40L activity with regards to IL-21 costimulation and differentiation of memory B-cells present in spleen (53) (Figure 2).

\section{IMMUNOGLOBULIN PRODUCTION}

Critical sites for the generation of antibody responses are the germinal centers in lymphoid follicles present in lymph nodes that also have been identified in transplanted organs $(4,54)$ where antigen-primed B-cells interact with T-cells, most of which are Tfh cells secreting IL-21. The B-cells are driven to undergo Ig isotype

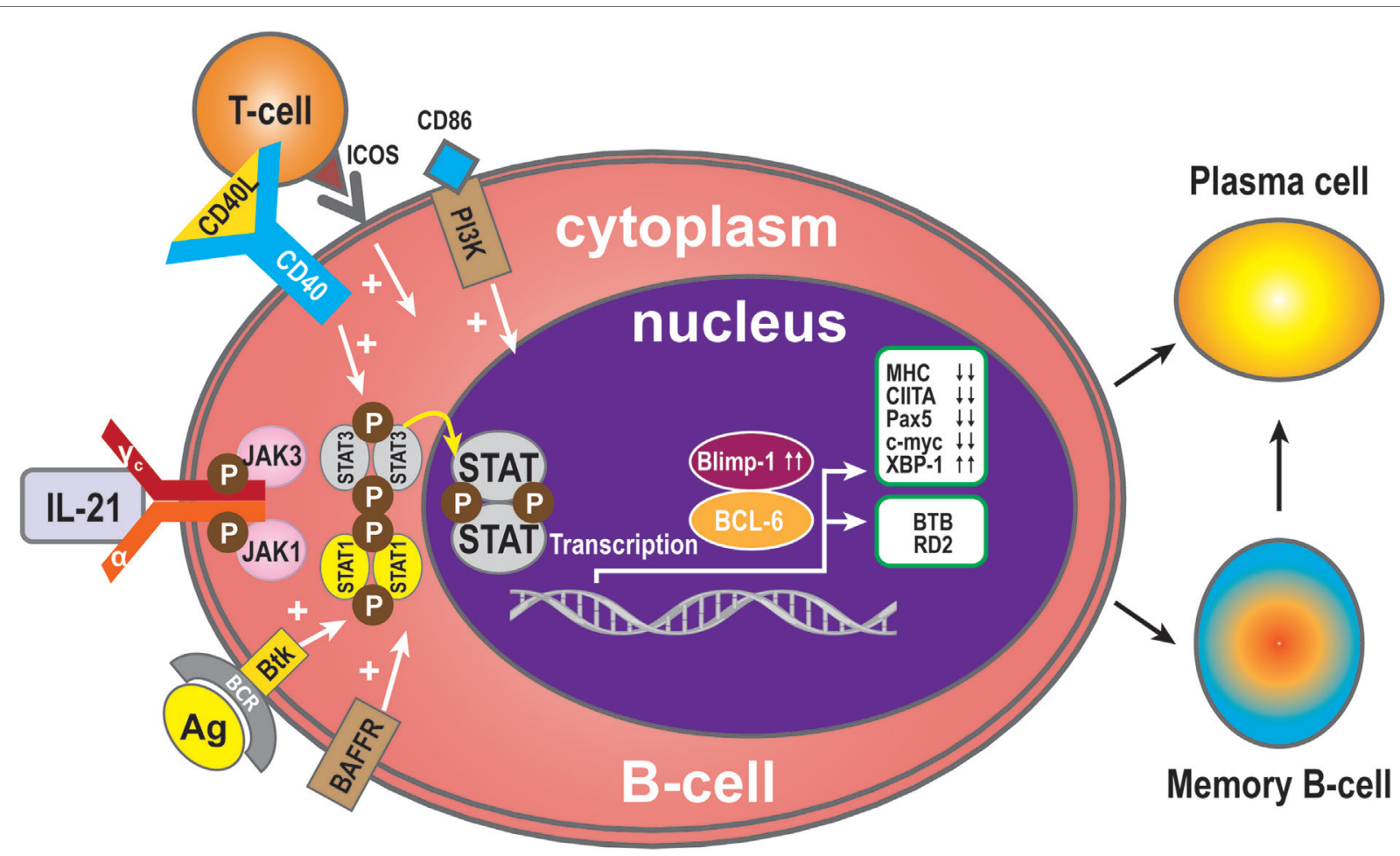

FIGURE 2 | B-cell activation and differentiation. Plasma cells are the main executors of B-cell regulation by the IL-21signal pathway. STAT3 is the dominant member of the STAT family in this respect. Transcription Blimp-1 has a positive role and BCL-6 a negative role in plasma cell maturation. Additionally, CD4OL, ICOS, CD86, and BAFF can promote B-cell differentiation to plasma cells, while MHC, CIITA, Pax5, and c-myc are switched off during B-cell differentiation to plasma cells or memory B-cells, and XBP-1 is induced. The transcription factor BCL-6 activates BTB, which is required for cell survival and proliferation, while RD2 prevents terminal differentiation of B-cells. 
switching, with SHM and secretion of high affinity antibodies (12, 55-58). Bryant et al. reported that IL-21 stimulates naive B-cells to mainly produce $\operatorname{IgM}^{+}$B-cells, while low frequencies of IgG and IgA secreted B-cells were also detected (59). When IgG was produced, IL-21 favors naive B-cells to develop into IgG1- and IgG3-secreting B-cells $(56,57,59-62)$. It has been reported that IgM-specific Abs targeting BCR and IL-21 costimulation also induce the expression of AID $(63,64)$. Interestingly, although AID catalyzes both class switch recombination (CSR) and SHM, only CSR is induced in naive human B-cells after stimulation by IL-21 and anti-CD40 $(45,47,60,65)$. The C-terminal of AID is required for CSR but not for SHM $(65,66)$, and it has been postulated that IL-21 induces AID activity only at the C terminus. Multiple studies have shown that IL-21 causes CSR of CD40-stimulated human naive splenic IgM+ $\mathrm{I}^{+}$-cells to IgG1 and IgG3, and CSR of CD40-stimulated cord blood B-cells to $\operatorname{IgA}(47,60)$. As well as the molecules described above, among the group of cytokines called bone morphogenetic proteins (BMPs) (67), BMP-2, -4, -6, and -7 inhibit CD40L/IL-21-induced production of IgM, IgG, and IgA. In memory B-cells, BMP-6 upregulated expression of DNA-binding protein inhibitor genes, but potently inhibited CD40L/IL-21-induced upregulation of the transcription factor XBP-1 (34). This factor is crucial for final stage in plasma cell differentiation (34). As described above, Btk is an efficient propagator of IL-21 signaling, critical for CSR in human B-cells and secretion of Ig (25). Additionally, the outcome of IL-21mediated Ig secretion depends on the presence of IL-4 and IL-10, which influence the outcome of IL-21-mediated CSR. IL-10 acts synergistically with IL-21 to induce secretion of IgA by CD40Lstimulated human B-cells, whereas IL-4 has an inhibitory effect (47). As shown by the group of Bromberg, IL-10 deficiency in $\mathrm{B}$-cells prevents transplantation tolerance, resulting in decreased follicular immune regulatory $\mathrm{CD} 4^{+} \mathrm{T}$-cells, a recently identified T cell subset, and increased IL-21 expression by Tfh cells in the B-cell and T-cell marginal zones (68). This has implications for our understanding of the mechanisms involved in tolerance and show at the same time that B cells play pivotal roles in the induction of this immune phenomenon (68). Interestingly, as with IL-21, IL-10, in combination with toll-like receptor (TLR), signaling also enhances phosphorylation of STAT3, resulting in increased IgG production. Hence, IL-21 and IL-10 increase the activity of the TLR-MyD88-STAT3 pathway in human B-cells by enhancing Ig production stimulated by STAT3 phosphorylation (69) (Figure 3).

\section{REGULATORY B (B10) CELLS}

Interleukin-21 may also modulate the immune response by immune-dampening regulatory mechanisms. One of these is performed by B10 cells, named for their ability to produce abundant

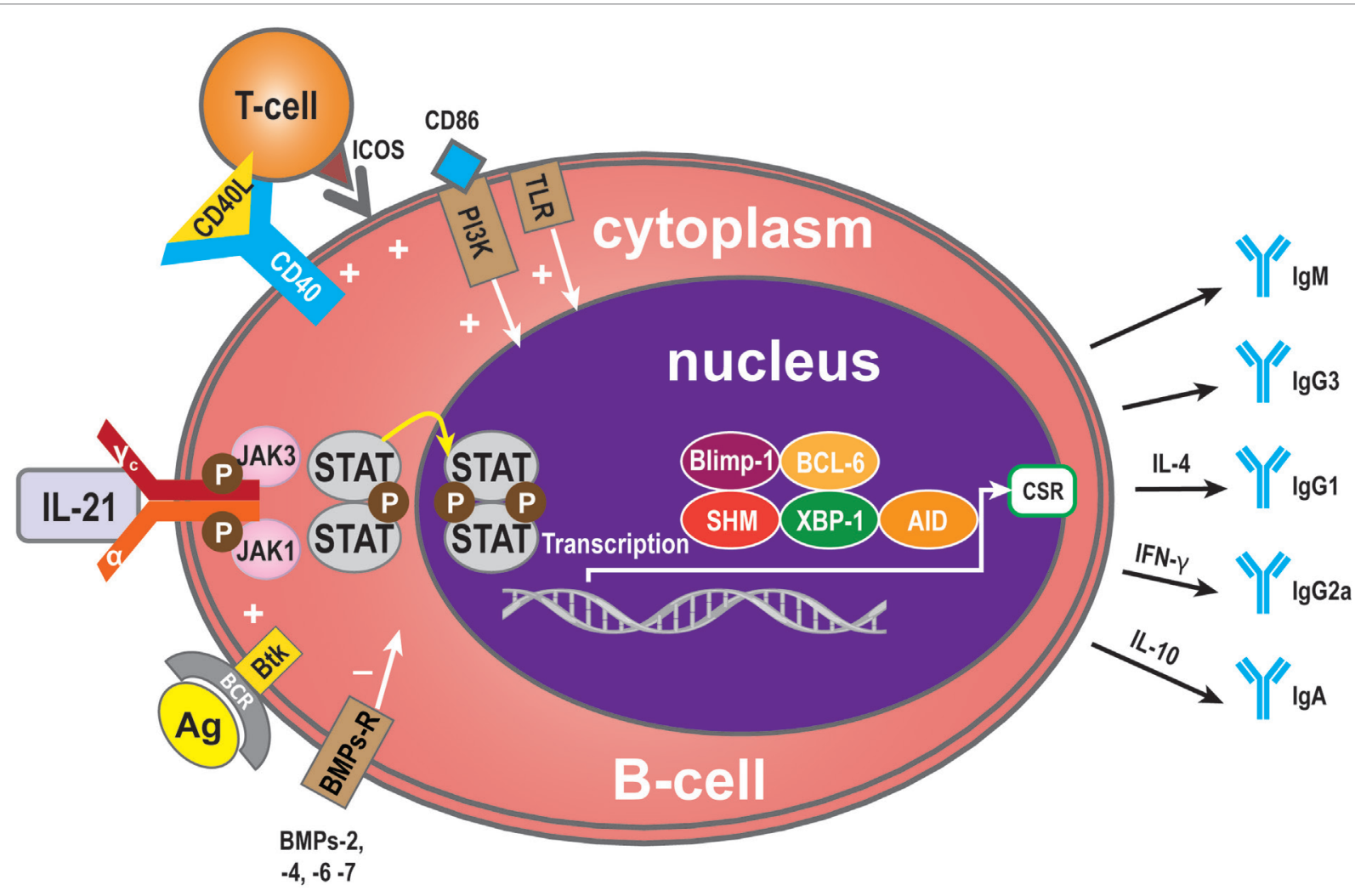

FIGURE 3 | Immunoglobulin (Ig) production. Ig is produced by plasma cells, so the signaling pathway for mediation of Ig production is similar to that for IL-21-mediated plasma cell maturation. Some molecules, however, have a specific role in Ig production: BMP-2, $-4,-6$, and -7 may exert a negative influence and Btk a positive influence. In addition, some cytokines contribute to Ig CSR. IL-4 can induce to IgG1 formation, IFN- $\gamma$ to IgG2a, and IL-10 to IgA. 

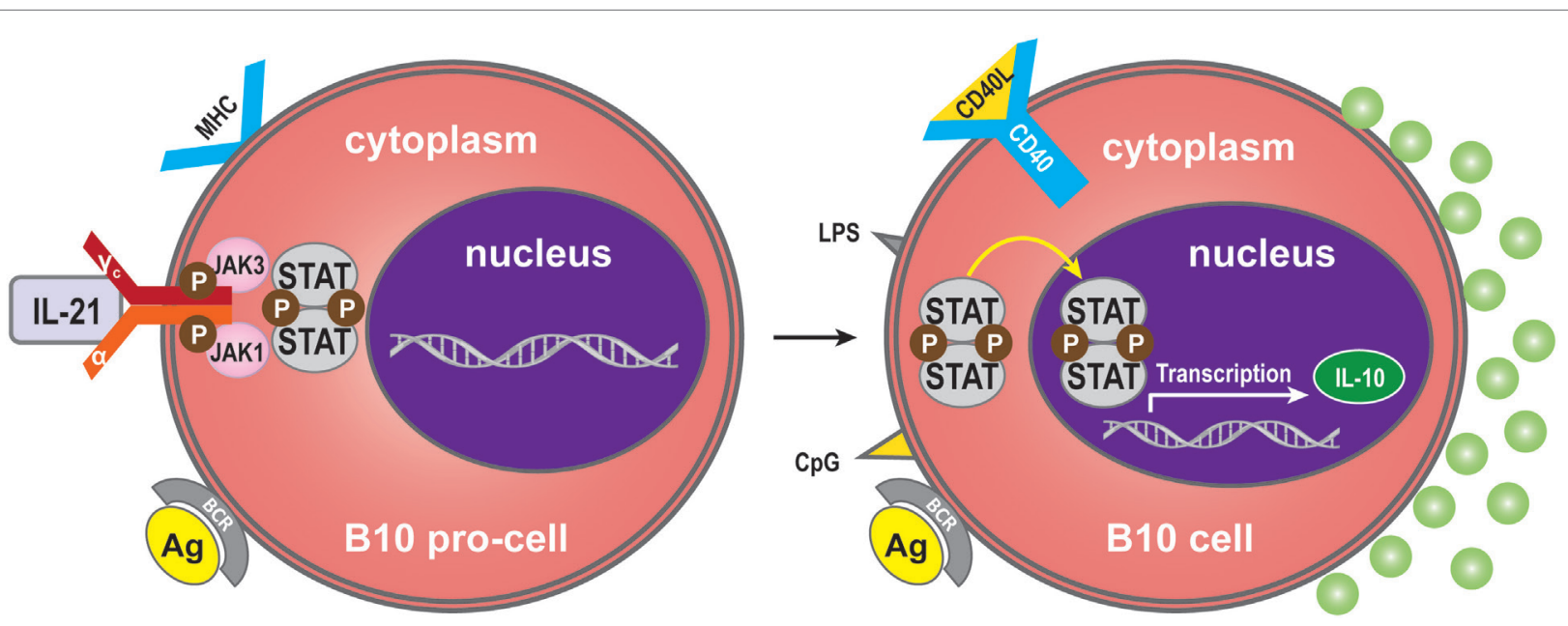

FIGURE 4 | Regulatory B (B10) cells. IL-21 binding to IL-21R expressed on B10 pro-cells may trigger B10 pro-cell maturation to B10 cells. Synergistically with MHC-II, LPS, CpG, or CD40 ligation stimulation can induce this cell subset to produce IL-10.

IL-10 (70). Expression of IL-10 is a common characteristic of regulatory immune cells, and B10 cells are thus referred to as regulatory B-cells $(71,72)$. The $\mathrm{B} 10$ cell subset represents $<1 \%$ of peripheral blood B-cells in humans (73). A high proportion of peripheral B10 cells and progenitor (pro)-B10 are present in the $\mathrm{CD} 24^{\mathrm{hi}} \mathrm{CD} 27^{+} \mathrm{B}$-cell subset, and approximately $60 \%$ also express CD38 (73). B10 progenitors and B10 cells have been identified in human (73). Ex vivo, human B10 progenitors can be driven to develop into B10 cells by lipopolysaccharide (LPS) or 5'-C-phosphate-G-3' (CpG), or by CD40 ligation. In vitro, IL-21/CD40-receptor signaling pathways can promote the development and expansion of B10 cells by four million-fold to suppress the immune response. IL-21R signaling, together with major histocompatibility complex class II and CD40 cognate, interacts with $\mathrm{CD} 4^{+} \mathrm{T}$-cells and although not required for B10 cell development, are necessary for B10 cell effector functions that result in antigen-specific responses. Interestingly, BCR ligation augments human B-cell IL-10 responses to CpG (74). Whether human B10 cells develop into antibody-secreting cells, or enter the memory B10 cell subset, remains to be determined (75). B10 cells may represent a subset, which is similar to regulatory T-cells (76) (Figure 4).

B10 cells are able to control the immune response, but an excessive reaction from these cells may also promote tumor cell growth or chronic infection (77). It is possible that regulatory fine tuning by B-cells and IL-21 production by T-cells might be a key factor in maintaining immune tolerance (78). Most investigations of B10 cells have concentrated on autoimmune diseases (79), but a few have assessed their role in transplantation (80). A mouse islet T-cell transplantation study has demonstrated that B10 cells control immune responses (81).

\section{B-CELL APOPTOSIS MEDIATED BY IL-21}

The effects of IL-21 on B cells depend on the costimulatory signals that are received. In the absence of signal from a
$\mathrm{T}$ cell (such as the $\mathrm{T}$ cell engaging CD40), BCR activation is required for IL-21-mediated B cell apoptosis $(15,29,35)$. The balance between STAT1 and STAT3 is critical for IL-21induced B-cell apoptosis in the IL-21 signaling pathway. STAT1 mainly acts in cell cycle arrest and apoptotic cell death $(45,47,82,83)$. By contrast, STAT3 mostly exerts an anti-apoptotic effect, especially in numerous malignancies where it is constitutively active (83). In some circumstances, IL-21 can induce apoptosis of B-cells activated via signals through the TLR, LPS, CpG, anti-IgM, and IL-4 (11, 15). Complete protection from IL-21-mediated apoptosis was not inhibited by other molecules involved in apoptotic pathways. Functional studies have demonstrated that IL-21 substantially inhibited proliferation and Bim-dependent apoptosis of activated mouse B-cells (47). Hagn et al. reported that CpG together with IL-21 may enhance their apoptosis-inducing and immunogenizing effects (84). It is therefore possible that combining CpG with IL-21 could more effectively induce apoptosis in B-cells than CpG or IL-21 alone. Furthermore, IL-21 can inhibit B-cell proliferation when receiving a strong signal via TLR while preventing apoptosis of B-cells via upregulation of B-cell leukemia/lymphoma-X linked (BCL-XL), an anti-apoptotic protein of the BCL-2 homology 3 (BH3) family $(11,85)$ (Figure 5). From this viewpoint, IL-21 appears to act as an immunosuppressive cytokine on B-cells. This finding indicates that the apoptotic effects of IL-21 may only be relevant in situations where a humoral immune response is improperly triggered, thereby shutting down at least one arm of the immune system before extensive damage is done (7).

\section{GRANZYME B PRODUCTION BY B-CELLS}

Interleukin-21 can induce BCR-stimulated human B-cells to differentiate into granzyme B-expressing cytotoxic cells ( $\mathrm{GrB}$ ) in a STAT3-dependent manner in the absence of a CD40 signal 


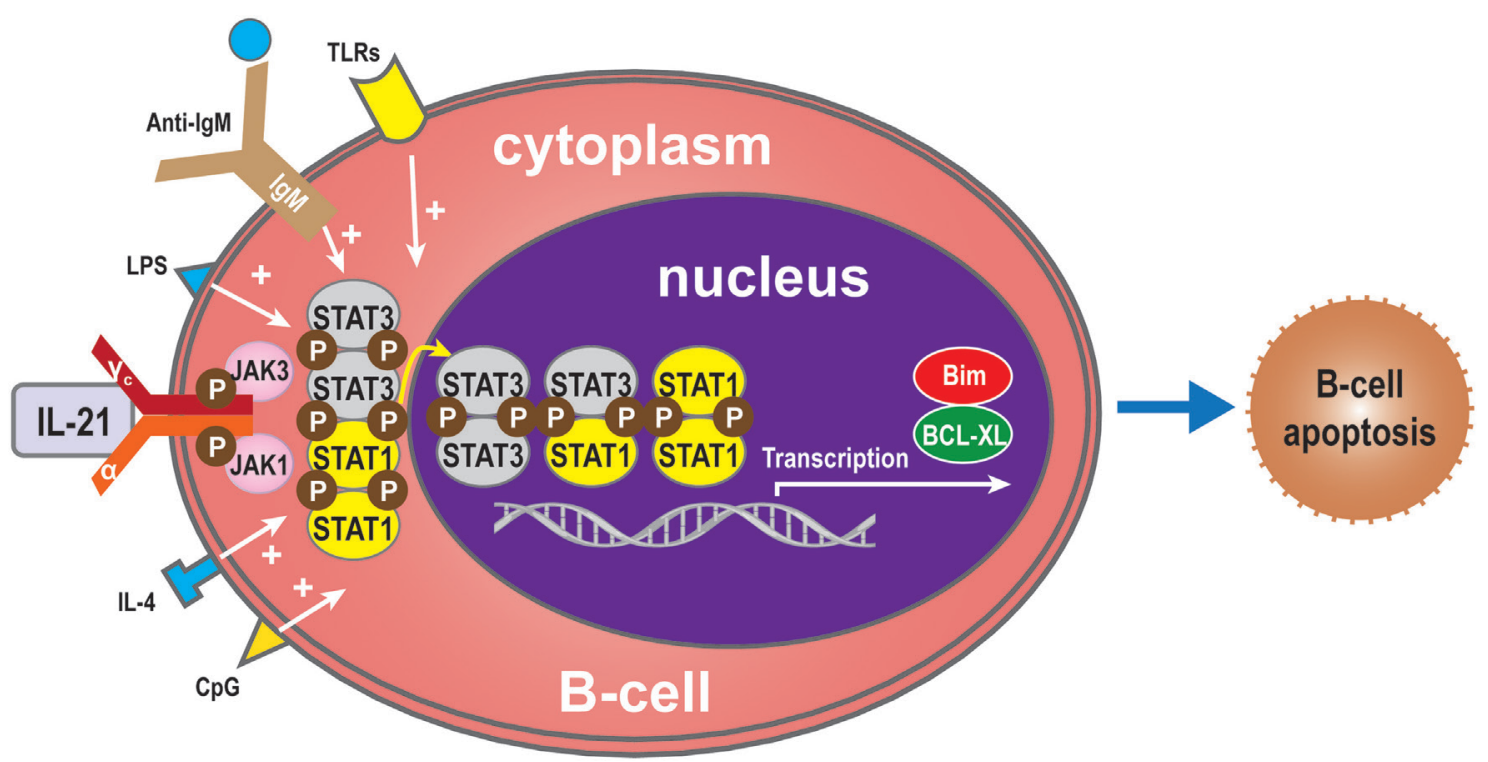

FIGURE 5 | B-cell apoptosis. IL-21 can also induce apoptosis of B-cells when activated by LPS, TLRs, CpG, anti-lgM, or IL-4 in the absence of T-cell signals. In the absence of such molecules, the balance between STAT1 and STAT3 regulates B-cell apoptosis via the IL-21 signaling pathway. STAT1 induces cell death, while, conversely, STAT3 exerts an anti-apoptotic effect. Bim also plays an apoptotic role and BCL-XL an anti-apoptotic role.

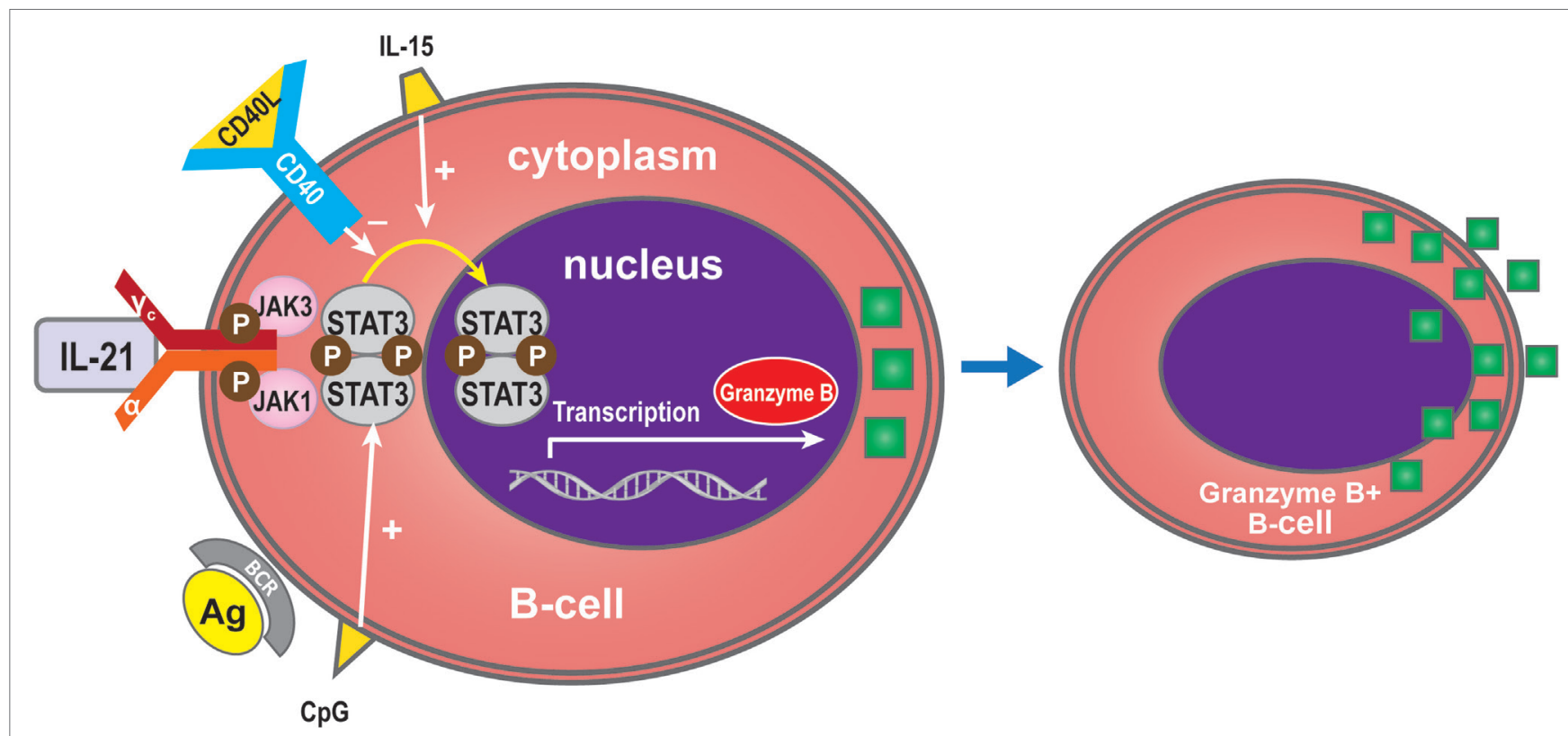

FIGURE 6 | Granzyme B expression by B-cells. IL-21 can induce BCR-stimulated B-cells to differentiate into granzyme B (GrB), an effect which is dependent on STAT3 and which is promoted by IL-15 or CpG. CD40 inhibits differentiation into GrB-cells.

(31, 77, 86-88). GrB ${ }^{+}$B-cell numbers are dependent on IL-21 production, and increasing doses of anti-IL-21 decreased the number of GrB-expressing B-cells in co-culture systems (78). The increase in $\mathrm{GrB}^{+} \mathrm{B}$-cells in the circulation of tolerant recipients may be due to a direct effect of IL-21 (78). GrB secreted by $B$ cells may play a key role in the regulation of immune responses $(78,89)$. Xu et al. showed that IL-21 initially triggers transcription of the GrB gene in B-cells, while STAT3 is required for GrB synthesis in PCs activated by IL-21 and IL-15. The defect in GrB formation in STAT3-deficient B-cells might arise from a lack of cell proliferation and differentiation (88). Recent in vitro studies have indicated that CD40 signaling in B-cells inhibits their differentiation into $\mathrm{GrB}^{+}$cells $(31,77)$ (Figure 6). 


\section{IL-21 AS A POSSIBLE PLAYER IN ALLOREACTIVITY AFTER TRANSPLANTATION}

Antibody-mediated rejection is a major problem after organ transplantation mediated by anti-HLA antibodies and donorspecific antibodies (DSA). This poorly defined alloimmune response is refractory to treatment with conventional immunosuppression (1). From our recent studies, we know that in this process, B-cells can be activated by IL-21-producing Tfh cells and differentiate into Ig-producing plasma cells. We reported that these Tfh cells as well as B-cells infiltrate the allograft during rejection and colocalize in follicular-like structures in the transplanted kidney $(4,18)$. These tide clusters of $\mathrm{T}$ and B-cells form highly organized lymphoid structures named tertiary lymphoid organs (TLOs). Associations between the presence of these TLO and poor graft outcome have been reported (90-92). In contrast, $\mathrm{Xu}$ et al. reported that IL-17, and not IL-21, is responsible for lymphoid neogenesis. Therefore, they suggested that Th17, but not Tfh, cells could play a role in the process of lymphoid neogenesis (93). It is likely that infiltrated and organized $\mathrm{T}$ and $\mathrm{B}$-cells contribute to the anti-donor response by antigen presentation of B cells and by help of Tfh cells to the infiltrated B-cells. Besides IL-21, the capacity of Tfh cells to provide help to B-cells depends upon the acquisition of molecules that are known to play functional roles in T-cell-B-cell interactions, such as CD40 ligand, inducible co-stimulator (ICOS), and programed death 1 (PD-1) $(18,33,94,95)$.

In organ transplantation, specifically targeting B-cells to decrease plasma cell differentiation by either IL-21-dependent B cell apoptosis or IL-21R blockade may provide novel approaches for the prevention of the development of de novo DSA and treatment of antibody-mediated rejection.

The first approach is speculative and based on the finding that IL-21 induces B-cell apoptosis when costimulation signals are absent $(15,29,35)$. At the same time, IL-21 might stimulate the cytolytic functions of alloantigen activated CD8 T cells, the aggressors in acute rejection $(96,97)$. Therefore, we should be careful with IL-21 cytokine treatment. This strategy should first be tested in experimental animal models by using various concentrations of IL-21 to define if B cell apoptosis and T cell cytotoxicity rely on the same or different concentrations of IL-21. This knowledge is helpful to better understand the role of IL-21 in B-cell-mediated immune processes such as apoptotic cell death.

The second approach could be blockade of the IL-21 pathway proven to affect the production of pathogenic immunoglobulins in animal models of autoimmune diseases. In these studies, blockade of the IL-21R signaling pathway reduced B-cellmediated diseases (98). Also, in a mouse model of islet transplantation, mIL-21R-Fc combined with CTLA-4-Ig diminished T-cell and B-cell effector functions, and tolerance was induced in a subgroup of treated animals (99). It is critical to determine whether neutralizing the IL-21 function also inhibits production of anti-HLA antibodies and DSA in organ transplant recipients. So far, such studies have not been conducted, but based on the

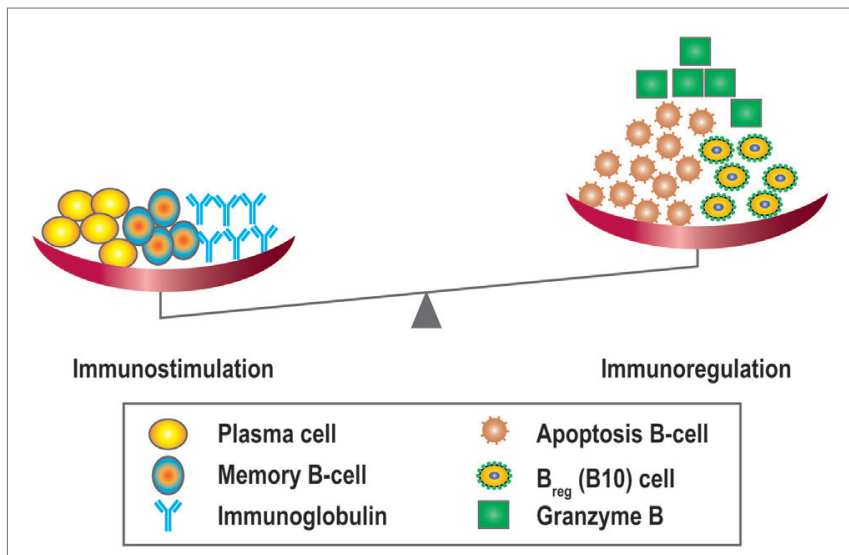

FIGURE 7 | Overview of the immunostimulatory and immunoregulatory effects of IL-21. IL-21 promotes B-cell proliferation, plasma cell differentiation, B-cell memory, and Ig class switching, and is also important for the development of IL-10 + regulatory B-cells (Bregs/B10), $\mathrm{B}$-cell apoptosis, and granzyme B producing cells.

biological functions of IL-21, the promising findings in animal models for autoimmune diseases and in vitro studies, targeting the IL-21 pathway could be expected to reduce the incidence of antibody-mediated alloreactivity. Our studies using peripheral T-cells and B-cells derived from kidney transplant patients showed that the interaction between IL-21-producing Tfh cells and B-cells could be inhibited by an IL-21 receptor antagonist. In these co-cultures, B-cell differentiation and IgM and IgG production were diminished (4). We believe that IL-21-producing Tfh cells play a dominant role in alloreactivity and should be targeted by novel immunosuppressive agents.

Like many other cytokines, IL-21 has multiple functions. In addition to its actions in B-cell apoptosis and differentiation it also drives regulatory $\mathrm{B} 10$ responses. These cells have been shown to suppress T-cell-mediated rejection induced by mismatched MHC molecules and prolong allogeneic islet T-cell survival, suggesting a potential regulatory role for $\mathrm{B} 10$ cells in organ transplantation $(80,81)$. Since IL-21 can promote regulatory B10 cell proliferation, harnessing the anti-inflammatory properties of B10 cells by anti-IL-21 agents could potentially stimulate antibody-mediated rejection and promote a less favorable tolerogeneic environment by modulating the plasma cell/Breg (B10) balance (68) (Figure 7). Recently, another type of Bregs was described, which could be inhibited by anti-IL-21 treatment. The number of GrB-producing B-cells with regulatory properties was significantly higher in tolerant patients compared to patients with stable graft function (78). This observation suggests that targeting the IL-21R pathway with immunosuppressive agents may harness this cell population. Data in this area, however, remain sparse.

\section{CONCLUSION}

In general, IL-21 promotes humoral immunity, and IL-21 blockade may attenuate B-cell hyperactivity in which also 
costimulatory signals are involved. However, B-cells may have a dual effect, acting both as a driver and as a regulator of the immune system $(78,79,100)$. In B-cells that recognize $\mathrm{Ag}$ and receive T-cell help, IL-21 induces survival, proliferation, isotype switching, and differentiation to Ig-secreting plasma cells or GrBproducing B-cells. B-cells can also cause cell death or, in the form of regulatory $\mathrm{B} 10$ cells, can induce autoimmunity if they receive a strong signal via BCR, or via TLR, and IL-21 costimulation. An equilibrium between effector and suppresser cells is necessary to maintain B-cell homeostasis and the immune balance, especially for the prevention of antibody-mediated transplantation rejection. Future studies should focus on elucidating details of the signaling cascades and downstream changes in gene and protein expression within B-cells in response to IL-21, either alone or in combination with other molecules. This knowledge may

\section{REFERENCES}

1. Loupy A, Lefaucheur C, Vernerey D, Prugger C, Duong van Huyen JP, Mooney N, et al. Complement-binding anti-HLA antibodies and kidney-allograft survival. N Engl J Med (2013) 369(13):1215-26. doi:10.1056/ NEJMoa1302506

2. Westall GP, Snell GI. Antibody-mediated rejection in lung transplantation: fable, spin, or fact? Transplantation (2014) 98(9):927-30. doi:10.1097/ TP.0000000000000392

3. Loupy A, Suberbielle-Boissel C, Hill GS, Lefaucheur C, Anglicheau D, Zuber J, et al. Outcome of subclinical antibody-mediated rejection in kidney transplant recipients with preformed donor-specific antibodies. Am J Transplant (2009) 9(11):2561-70. doi:10.1111/j.1600-6143.2009.02813.x

4. de Graav GN, Dieterich M, Hesselink DA, Boer K, Clahsen-van Groningen MC, Kraaijeveld R, et al. Follicular T helper cells and humoral reactivity in kidney transplant patients. Clin Exp Immunol (2015) 180(2):329-40. doi:10.1111/cei.12576

5. Ville S, Poirier N, Branchereau J, Charpy V, Pengam S, Nerriere-Daguin V, et al. Anti-CD28 antibody and belatacept exert differential effects on mechanisms of renal allograft rejection. J Am Soc Nephrol (2016). doi:10.1681/ ASN.2015070774

6. Parrish-Novak J, Dillon SR, Nelson A, Hammond A, Sprecher C, Gross JA, et al. Interleukin 21 and its receptor are involved in NK cell expansion and regulation of lymphocyte function. Nature (2000) 408(6808):57-63. doi:10.1038/35040504

7. Mehta DS, Wurster AL, Grusby MJ. Biology of IL-21 and the IL-21 receptor. Immunol Rev (2004) 202:84-95. doi:10.1111/j.0105-2896.2004.00201.x

8. Kis LL, Salamon D, Persson EK, Nagy N, Scheeren FA, Spits H, et al. IL-21 imposes a type II EBV gene expression on type III and type I B cells by the repression of C- and activation of LMP-1-promoter. Proc Natl Acad Sci U S A (2010) 107(2):872-7. doi:10.1073/pnas.0912920107

9. Wan CK, Oh J, Li P, West EE, Wong EA, Andraski AB, et al. The cytokines IL-21 and GM-CSF have opposing regulatory roles in the apoptosis of conventional dendritic cells. Immunity (2013) 38(3):514-27. doi:10.1016/j. immuni.2013.02.011

10. Spolski R, Leonard WJ. Interleukin-21: basic biology and implications for cancer and autoimmunity. Annu Rev Immunol (2008) 26:57-79. doi:10.1146/ annurev.immunol.26.021607.090316

11. Gharibi T, Majidi J, Kazemi T, Dehghanzadeh R, Motallebnezhad M, Babaloo Z. Biological effects of IL-21 on different immune cells and its role in autoimmune diseases. Immunobiology (2016) 221(2):357-67. doi:10.1016/j.imbio.2015. 09.021

12. Crotty S. Follicular helper CD4 T cells (TFH). Annu Rev Immunol (2011) 29:621-63. doi:10.1146/annurev-immunol-031210-101400

13. Spaan M, Kreefft K, de Graav GN, Brouwer WP, de Knegt RJ, ten Kate FJ, et al. CD4+ CXCR5+ T cells in chronic HCV infection produce less IL-21, yet are efficient at supporting B cell responses. J Hepatol (2015) 62(2):303-10. doi:10.1016/j.jhep.2014.09.024 ultimately lead to an effective therapeutic strategy to overcome antibody-mediated rejection following transplantation, particularly by targeting the differentiation of B-cells into plasma cells via IL-21 signaling pathways.

\section{AUTHOR CONTRIBUTIONS}

$\mathrm{YW}, \mathrm{NB}, \mathrm{YS}, \mathrm{MH}, \mathrm{LW}$, and $\mathrm{CB}$ researched the literature and wrote the review.

\section{FUNDING}

This work was supported by a fund from the Science and Technology Department of Sichuan Province, Grant No. 2016JY0035.

14. Good KL, Bryant VL, Tangye SG. Kinetics of human B cell behavior and amplification of proliferative responses following stimulation with IL-21. J Immunol (2006) 177(8):5236-47. doi:10.4049/jimmunol.177.8.5236

15. Leonard WJ, Spolski R. Interleukin-21: a modulator of lymphoid proliferation, apoptosis and differentiation. Nat Rev Immunol (2005) 5(9):688-98. doi: $10.1038 /$ nri1688

16. Fichtner A, Susal C, Hocker B, Rieger S, Waldherr R, Westhoff JH, et al. Association of $\mathrm{Clq}$-fixing DSA with late graft failure in pediatric renal transplant recipients. Pediatr Nephrol (2016) 31(7):1157-66. doi:10.1007/ s00467-016-3322-8

17. Roux A, Bendib Le Lan I, Holifanjaniaina S, Thomas KA, Hamid AM, Picard $\mathrm{C}$, et al. Antibody-mediated rejection in lung transplantation: clinical outcomes and donor-specific antibody characteristics. Am J Transplant (2016) 16(4):1216-28. doi:10.1111/ajt.13589

18. Baan CC, de Graav GN, Boer K. T follicular helper cells in transplantation: the target to attenuate antibody-mediated allogeneic responses? Curr Transplant Rep (2014) 1(3):166-72. doi:10.1007/s40472-014-0019-4

19. Lederer SR, Kluth-Pepper B, Schneeberger H, Albert E, Land W, Feucht HE. Impact of humoral alloreactivity early after transplantation on the long-term survival of renal allografts. Kidney Int (2001) 59(1):334-41. doi:10.1046/j.1523-1755.2001.00495.x

20. Racusen LC, Colvin RB, Solez K, Mihatsch MJ, Halloran PF, Campbell PM, et al. Antibody-mediated rejection criteria - an addition to the Banff 97 classification of renal allograft rejection. Am J Transplant (2003) 3(6):708-14. doi:10.1034/j.1600-6143.2003.00072.x

21. Clatworthy MR. Targeting B cells and antibody in transplantation. Am J Transplant (2011) 11(7):1359-67. doi:10.1111/j.1600-6143.2011.03554.x

22. Stegall MD, Raghavaiah S, Gloor JM. The (re)emergence of B cells in organ transplantation. Curr Opin Organ Transplant (2010) 15(4):451-5. doi:10.1097/MOT.0b013e32833b9c11

23. Sarwal M, Chua MS, Kambham N, Hsieh SC, Satterwhite T, Masek M, et al. Molecular heterogeneity in acute renal allograft rejection identified by DNA microarray profiling. N Engl J Med (2003) 349(2):125-38. doi:10.1056/ NEJMoa035588

24. Hippen BE, DeMattos A, Cook WJ, Kew CE II, Gaston RS. Association of CD20+ infiltrates with poorer clinical outcomes in acute cellular rejection of renal allografts. Am J Transplant (2005) 5(9):2248-52. doi:10.1111/j.1600-6143.2005.01009.x

25. Wang SP, Iwata S, Nakayamada S, Niiro H, Jabbarzadeh-Tabrizi S, Kondo $\mathrm{M}$, et al. Amplification of IL-21 signalling pathway through Bruton's tyrosine kinase in human B cell activation. Rheumatology (Oxford) (2015) 54(8):1488-97. doi:10.1093/rheumatology/keu532

26. Fina D, Fantini MC, Pallone F, Monteleone G. Role of interleukin-21 in inflammation and allergy. Inflamm Allergy Drug Targets (2007) 6(1):63-8. doi: $10.2174 / 187152807780077246$

27. Shifera AS, Leong D, Hardin JA. Vitamin D does not modulate NF-kappaB activity in Jurkat T cells. Immunol Lett (2010) 131(2):151-8. doi:10.1016/j. imlet.2010.04.001 
28. Ding BB, Bi E, Chen H, Yu JJ, Ye BH. IL-21 and CD40L synergistically promote plasma cell differentiation through upregulation of Blimp-1 in human B cells. J Immunol (2013) 190(4):1827-36. doi:10.4049/jimmunol.1201678

29. Ozaki K, Spolski R, Ettinger R, Kim HP, Wang G, Qi CF, et al. Regulation of $B$ cell differentiation and plasma cell generation by IL-21, a novel inducer of Blimp-1 and Bcl-6. JImmunol (2004) 173(9):5361-71. doi:10.4049/ jimmunol.173.9.5361

30. Simard N, Konforte D, Tran AH, Esufali J, Leonard WJ, Paige CJ. Analysis of the role of IL-21 in development of murine B cell progenitors in the bone marrow. J Immunol (2011) 186(9):5244-53. doi:10.4049/jimmunol.1004040

31. Kaltenmeier C, Gawanbacht A, Beyer T, Lindner S, Trzaska T, van der Merwe JA, et al. CD4+ T cell-derived IL-21 and deprivation of CD40 signaling favor the in vivo development of granzyme B-expressing regulatory B cells in HIV patients. J Immunol (2015) 194(8):3768-77. doi:10.4049/jimmunol.1402568

32. Zotos D, Coquet JM, Zhang Y, Light A, D'Costa K, Kallies A, et al. IL-21 regulates germinal center $B$ cell differentiation and proliferation through a B cell-intrinsic mechanism. J Exp Med (2010) 207(2):365-78. doi:10.1084/ jem.20091777

33. Crotty S. A brief history of T cell help to B cells. Nat Rev Immunol (2015) 15(3):185-9. doi:10.1038/nri3803

34. Huse K, Bakkebo M, Oksvold MP, Forfang L, Hilden VI, Stokke T, et al. Bone morphogenetic proteins inhibit CD40L/IL-21-induced Ig production in human B cells: differential effects of BMP-6 and BMP-7. Eur J Immunol (2011) 41(11):3135-45. doi:10.1002/eji.201141558

35. Jin H, Carrio R, Yu A, Malek TR. Distinct activation signals determine whether IL-21 induces B cell costimulation, growth arrest, or Bim-dependent apoptosis. J Immunol (2004) 173(1):657-65. doi:10.4049/jimmunol.173.1.657

36. Lim JY, Park MJ, Im KI, Kim N, Park HS, Lee SH, et al. Interleukin 21 blockade modulates activated $\mathrm{T}$ - and B-cell homeostasis via B-cell activating factor pathway-mediated inhibition in a murine model of acute graftversus-host disease. Exp Hematol (2015) 43(1):23-31.e1-2. doi:10.1016/j. exphem.2014.09.005

37. Konforte D, Paige CJ. Identification of cellular intermediates and molecular pathways induced by IL-21 in human B cells. J Immunol (2006) 177(12):8381-92. doi:10.4049/jimmunol.177.12.8381

38. de Totero D, Meazza R, Zupo S, Cutrona G, Matis S, Colombo M, et al. Interleukin-21 receptor (IL-21R) is up-regulated by CD40 triggering and mediates proapoptotic signals in chronic lymphocytic leukemia B cells. Blood (2006) 107(9):3708-15. doi:10.1182/blood-2005-09-3535

39. Zeng R, Spolski R, Casas E, Zhu W, Levy DE, Leonard WJ. The molecular basis of IL-21-mediated proliferation. Blood (2007) 109(10):4135-42. doi:10.1182/blood-2006-10-054973

40. Avery DT, Deenick EK, Ma CS, Suryani S, Simpson N, Chew GY, et al. B cell-intrinsic signaling through IL-21 receptor and STAT3 is required for establishing long-lived antibody responses in humans. J Exp Med (2010) 207(1):155-71. doi:10.1084/jem.20091706

41. Moens L, Tangye SG. Cytokine-mediated regulation of plasma cell generation: IL-21 takes center stage. Front Immunol (2014) 5:65. doi:10.3389/ fimmu.2014.00065

42. Lee SK, Rigby RJ, Zotos D, Tsai LM, Kawamoto S, Marshall JL, et al. B cell priming for extrafollicular antibody responses requires Bcl- 6 expression by $\mathrm{T}$ cells. J Exp Med (2011) 208(7):1377-88. doi:10.1084/jem.20102065

43. Shapiro-Shelef M, Lin KI, McHeyzer-Williams LJ, Liao J, McHeyzer-Williams MG, Calame K. Blimp-1 is required for the formation of immunoglobulin secreting plasma cells and pre-plasma memory B cells. Immunity (2003) 19(4):607-20. doi:10.1016/S1074-7613(03)00267-X

44. Shaffer AL, Lin KI, Kuo TC, Yu X, Hurt EM, Rosenwald A, et al. Blimp-1 orchestrates plasma cell differentiation by extinguishing the mature B cell gene expression program. Immunity (2002) 17(1):51-62. doi:10.1016/ S1074-7613(02)00335-7

45. Diehl SA, Schmidlin H, Nagasawa M, van Haren SD, Kwakkenbos MJ, Yasuda E, et al. STAT3-mediated up-regulation of BLIMP1 Is coordinated with BCL6 down-regulation to control human plasma cell differentiation. J Immunol (2008) 180(7):4805-15. doi:10.4049/jimmunol.180.7.4805

46. Shaffer AL, Shapiro-Shelef M, Iwakoshi NN, Lee AH, Qian SB, Zhao H, et al. XBP1, downstream of Blimp-1, expands the secretory apparatus and other organelles, and increases protein synthesis in plasma cell differentiation. Immunity (2004) 21(1):81-93. doi:10.1016/j.immuni.2004.06.010
47. Konforte D, Simard N, Paige CJ. IL-21: an executor of B cell fate. J Immunol (2009) 182(4):1781-7. doi:10.4049/jimmunol.0803009

48. Scheeren FA, Naspetti M, Diehl S, Schotte R, Nagasawa M, Wijnands E, et al. STAT5 regulates the self-renewal capacity and differentiation of human memory B cells and controls Bcl-6 expression. Nat Immunol (2005) 6(3):303-13. doi:10.1038/ni1172

49. Shaffer AL, Yu X, He Y, Boldrick J, Chan EP, Staudt LM. BCL-6 represses genes that function in lymphocyte differentiation, inflammation, and cell cycle control. Immunity (2000) 13(2):199-212. doi:10.1016/S1074-7613(00)00020-0

50. Huang C, Melnick A. Mechanisms of action of BCL6 during germinal center B cell development. Sci China Life Sci (2015) 58(12):1226-32. doi:10.1007/ s11427-015-4919-z

51. Attridge K, Kenefeck R, Wardzinski L, Qureshi OS, Wang CJ, Manzotti C, et al. IL-21 promotes CD4 T cell responses by phosphatidylinositol 3-kinase-dependent upregulation of CD86 on B cells. J Immunol (2014) 192(5):2195-201. doi:10.4049/jimmunol.1302082

52. Berglund LJ, Avery DT, Ma CS, Moens L, Deenick EK, Bustamante J, et al. IL-21 signalling via STAT3 primes human naive B cells to respond to IL-2 to enhance their differentiation into plasmablasts. Blood (2013) 122(24):394050. doi:10.1182/blood-2013-06-506865

53. Karnell JL, Ettinger R. The interplay of IL-21 and BAFF in the formation and maintenance of human B cell memory. Front Immunol (2012) 3:2. doi:10.3389/fimmu.2012.00002

54. Victora GD, Nussenzweig MC. Germinal centers. Annu Rev Immunol (2012) 30:429-57. doi:10.1146/annurev-immunol-020711-075032

55. Nutt SL, Tarlinton DM. Germinal center B and follicular helper T cells: siblings, cousins or just good friends? Nat Immunol (2011) 12(6):472-7. doi:10.1038/ni.2019

56. Eto D, Lao C, DiToro D, Barnett B, Escobar TC, Kageyama R, et al. IL-21 and IL- 6 are critical for different aspects of B cell immunity and redundantly induce optimal follicular helper CD4 T cell (Tfh) differentiation. PLoS One (2011) 6(3):e17739. doi:10.1371/journal.pone.0017739

57. Linterman MA, Beaton L, Yu D, Ramiscal RR, Srivastava M, Hogan JJ, et al. IL-21 acts directly on B cells to regulate Bcl-6 expression and germinal center responses. J Exp Med (2010) 207(2):353-63. doi:10.1084/jem.20091738

58. Ma CS, Deenick EK, Batten M, Tangye SG. The origins, function, and regulation of T follicular helper cells. JExp Med (2012) 209(7):1241-53. doi:10.1084/jem.20120994

59. Bryant VL, Ma CS, Avery DT, Li Y, Good KL, Corcoran LM, et al. Cytokinemediated regulation of human B cell differentiation into Ig-secreting cells: predominant role of IL-21 produced by CXCR5+ T follicular helper cells. J Immunol (2007) 179(12):8180-90. doi:10.4049/jimmunol.179.12.8180

60. Avery DT, Bryant VL, Ma CS, de Waal Malefyt R, Tangye SG. IL-21-induced isotype switching to IgG and IgA by human naive B cells is differentially regulated by IL-4. JImmunol (2008) 181(3):1767-79. doi:10.4049/ jimmunol.181.3.1767

61. Pene J, Gauchat JF, Lecart S, Drouet E, Guglielmi P, Boulay V, et al. Cutting edge: IL-21 is a switch factor for the production of IgG1 and IgG3 by human B cells. J Immunol (2004) 172(9):5154-7. doi:10.4049/jimmunol.172.9.5154

62. Ozaki K, Spolski R, Feng CG, Qi CF, Cheng J, Sher A, et al. A critical role for IL-21 in regulating immunoglobulin production. Science (2002) 298(5598):1630-4. doi:10.1126/science.1077002

63. Pallikkuth S, Parmigiani A, Pahwa S. Role of IL-21 and IL-21 receptor on B cells in HIV infection. Crit Rev Immunol (2012) 32(2):173-95. doi:10.1615/ CritRevImmunol.v32.i2.50

64. Saito T, Kitayama D, Sakamoto A, Tsuruoka N, Arima M, Hatano M, et al. Effective collaboration between IL-4 and IL-21 on B cell activation. Immunobiology (2008) 213(7):545-55. doi:10.1016/j.imbio.2008.01.006

65. Roa S, Avdievich E, Peled JU, Maccarthy T, Werling U, Kuang FL, et al. Ubiquitylated PCNA plays a role in somatic hypermutation and class-switch recombination and is required for meiotic progression. Proc Natl Acad Sci U S A (2008) 105(42):16248-53. doi:10.1073/pnas.0808182105

66. Wu X, Geraldes P, Platt JL, Cascalho M. The double-edged sword of activation-induced cytidine deaminase. J Immunol (2005) 174(2):934-41. doi:10.4049/jimmunol.174.2.934

67. Reddi AH, Reddi A. Bone morphogenetic proteins (BMPs): from morphogens to metabologens. Cytokine Growth Factor Rev (2009) 20(5-6):341-2. doi:10.1016/j.cytogfr.2009.10.015 
68. Lal G, Kulkarni N, Nakayama Y, Singh AK, Sethi A, Burrell BE, et al. IL-10 from marginal zone precursor B cells controls the differentiation of Th17, Tfh and Tfr cells in transplantation tolerance. Immunol Lett (2016) 170:52-63. doi:10.1016/j.imlet.2016.01.002

69. Liu BS, Stoop JN, Huizinga TW, Toes RE. IL-21 enhances the activity of the TLR-MyD88-STAT3 pathway but not the classical TLR-MyD88-NF-kappaB pathway in human B cells to boost antibody production. J Immunol (2013) 191(8):4086-94. doi:10.4049/jimmunol.1300765

70. Mauri C, Gray D, Mushtaq N, Londei M. Prevention of arthritis by interleukin 10-producing B cells. J Exp Med (2003) 197(4):489-501. doi:10.1084/jem.20021293

71. Tedder TF, Leonard WJ. Autoimmunity: regulatory B cells - IL-35 and IL-21 regulate the regulators. Nat Rev Rheumatol (2014) 10(8):452-3. doi:10.1038/ nrrheum.2014.95

72. Franquesa M, Mensah FK, Huizinga R, Strini T, Boon L, Lombardo E, et al. Human adipose tissue-derived mesenchymal stem cells abrogate plasmablast formation and induce regulatory B cells independently of T helper cells. Stem Cells (2015) 33(3):880-91. doi:10.1002/stem.1881

73. Iwata Y, Matsushita T, Horikawa M, Dilillo DJ, Yanaba K, Venturi GM, et al. Characterization of a rare IL-10-competent B-cell subset in humans that parallels mouse regulatory B10 cells. Blood (2011) 117(2):530-41. doi:10.1182/ blood-2010-07-294249

74. Bouaziz JD, Calbo S, Maho-Vaillant M, Saussine A, Bagot M, Bensussan A, et al. IL10 produced by activated human B cells regulates CD4(+) T-cell activation in vitro. Eur J Immunol (2010) 40(10):2686-91. doi:10.1002/eji.201040673

75. Kalampokis I, Yoshizaki A, Tedder TF. IL-10-producing regulatory B cells (B10 cells) in autoimmune disease. Arthritis Res Ther (2013) 15(Suppl 1):S1. doi:10.1186/ar3907

76. Gondek DC, Lu LF, Quezada SA, Sakaguchi S, Noelle RJ. Cutting edge: contact-mediated suppression by CD4+CD25+ regulatory cells involves a granzyme B-dependent, perforin-independent mechanism. JImmunol (2005) 174(4):1783-6. doi:10.4049/jimmunol.174.4.1783

77. Lindner S, Dahlke K, Sontheimer K, Hagn M, Kaltenmeier C, Barth TF, et al. Interleukin 21-induced granzyme B-expressing B cells infiltrate tumors and regulate T cells. Cancer Res (2013) 73(8):2468-79. doi:10.1158/0008-5472.CAN-12-3450

78. Chesneau M, Michel L, Dugast E, Chenouard A, Baron D, Pallier A, et al. Tolerant kidney transplant patients produce B cells with regulatory properties. J Am Soc Nephrol (2015) 26(10):2588-98. doi:10.1681/ASN.2014040404

79. Bouaziz JD, Yanaba K, Tedder TF. Regulatory B cells as inhibitors of immune responses and inflammation. Immunol Rev (2008) 224:201-14. doi:10.1111/j.1600-065X.2008.00661.x

80. Bao Y, Xiu DR. Adaptive transfer of B10 cells: a novel therapy for chronic rejection after solid organ transplantation. Med Hypotheses (2013) 81(1):1013. doi:10.1016/j.mehy.2013.03.037

81. Ding Q, Yeung M, Camirand G, Zeng Q, Akiba H, Yagita H, et al. Regulatory B cells are identified by expression of TIM-1 and can be induced through TIM-1 ligation to promote tolerance in mice. J Clin Invest (2011) 121(9):3645-56. doi:10.1172/JCI46274

82. Durbin JE, Hackenmiller R, Simon MC, Levy DE. Targeted disruption of the mouse Stat 1 gene results in compromised innate immunity to viral disease. Cell (1996) 84(3):443-50. doi:10.1016/S0092-8674(00)81289-1

83. Stephanou A, Latchman DS. Opposing actions of STAT-1 and STAT-3. Growth Factors (2005) 23(3):177-82. doi:10.1080/08977190500178745

84. Hagn M, Blackwell SE, Beyer T, Ebel V, Fabricius D, Lindner S, et al. B-CLL cells acquire APC- and CTL-like phenotypic characteristics after stimulation with CpG ODN and IL-21. Int Immunol (2014) 26(7):383-95. doi:10.1093/ intimm/dxu001

85. Pellat-Deceunynck C, Defrance T. The origin of the plasma-cell heterogeneity. Front Immunol (2015) 6:5. doi:10.3389/fimmu.2015.00005

86. Hagn M, Belz GT, Kallies A, Sutton VR, Thia KY, Tarlinton DM, et al. Activated mouse B cells lack expression of granzyme B. J Immunol (2012) 188(8):3886-92. doi:10.4049/jimmunol.1103285
87. Hagn M, Sontheimer K, Dahlke K, Brueggemann S, Kaltenmeier C, Beyer $\mathrm{T}$, et al. Human B cells differentiate into granzyme B-secreting cytotoxic B lymphocytes upon incomplete T-cell help. Immunol Cell Biol (2012) 90(4):457-67. doi:10.1038/icb.2011.64

88. Xu W, Narayanan P, Kang N, Clayton S, Ohne Y, Shi P, et al. Human plasma cells express granzyme B. Eur J Immunol (2014) 44(1):275-84. doi:10.1002/ eji.201343711

89. Hagn M, Jahrsdorfer B. Why do human B cells secrete granzyme B? Insights into a novel B-cell differentiation pathway. Oncoimmunology (2012) 1(8):1368-75. doi:10.4161/onci.22354

90. Einecke G, Reeve J, Mengel M, Sis B, Bunnag S, Mueller TF, et al. Expression of $\mathrm{B}$ cell and immunoglobulin transcripts is a feature of inflammation in late allografts. Am J Transplant (2008) 8(7):1434-43. doi:10.1111/j.1600-6143.2008.02232.x

91. Thaunat O, Field AC, Dai J, Louedec L, Patey N, Bloch MF, et al. Lymphoid neogenesis in chronic rejection: evidence for a local humoral alloimmune response. Proc Natl Acad Sci U S A (2005) 102(41):14723-8. doi:10.1073/ pnas.0507223102

92. Deteix C, Attuil-Audenis V, Duthey A, Patey N, McGregor B, Dubois V, et al. Intragraft Th17 infiltrate promotes lymphoid neogenesis and hastens clinical chronic rejection. JImmunol (2010) 184(9):5344-51. doi:10.4049/ jimmunol.0902999

93. Xu X, Han Y, Wang Q, Cai M, Qian Y, Wang X, et al. Characterisation of tertiary lymphoid organs in explanted rejected donor kidneys. Immunol Invest (2016) 45(1):38-51. doi:10.3109/08820139.2015.1085394

94. Nojima T, Haniuda K, Moutai T, Matsudaira M, Mizokawa S, Shiratori I, et al. In-vitro derived germinal centre B cells differentially generate memory B or plasma cells in vivo. Nat Commun (2011) 2:465. doi:10.1038/ncomms1475

95. Choi YS, Kageyama R, Eto D, Escobar TC, Johnston RJ, Monticelli L, et al. ICOS receptor instructs $\mathrm{T}$ follicular helper cell versus effector cell differentiation via induction of the transcriptional repressor Bcl6. Immunity (2011) 34(6):932-46. doi:10.1016/j.immuni.2011.03.023

96. Xie XJ, Ye YF, Zhou L, Xie HY, Jiang GP, Feng XW, et al. Th17 promotes acute rejection following liver transplantation in rats. J Zhejiang Univ Sci B (2010) 11(11):819-27. doi:10.1631/jzus.B1000030

97. Baan CC, Balk AH, Dijke IE, Korevaar SS, Peeters AM, de Kuiper RP, et al. Interleukin-21: an interleukin-2 dependent player in rejection processes. Transplantation (2007) 83(11):1485-92. doi:10.1097/01. tp.0000264998.23349.54

98. Young DA, Hegen M, Ma HL, Whitters MJ, Albert LM, Lowe L, et al. Blockade of the interleukin-21/interleukin-21 receptor pathway ameliorates disease in animal models of rheumatoid arthritis. Arthritis Rheum (2007) 56(4):1152-63. doi:10.1002/art.22452

99. Petrelli A, Carvello M, Vergani A, Lee KM, Tezza S, Du M, et al. IL-21 is an antitolerogenic cytokine of the late-phase alloimmune response. Diabetes (2011) 60(12):3223-34. doi:10.2337/db11-0880

100. Evans JG, Chavez-Rueda KA, Eddaoudi A, Meyer-Bahlburg A, Rawlings DJ, Ehrenstein MR, et al. Novel suppressive function of transitional 2 B cells in experimental arthritis. J Immunol (2007) 178(12):7868-78. doi:10.4049/ jimmunol.178.12.7868

Conflict of Interest Statement: The authors declare that the research was conducted in the absence of any commercial or financial relationships that could be construed as a potential conflict of interest.

Copyright (c) 2016 Wu, van Besouw, Shi, Hoogduijn, Wang and Baan. This is an open-access article distributed under the terms of the Creative Commons Attribution License (CC BY). The use, distribution or reproduction in other forums is permitted, provided the original author(s) or licensor are credited and that the original publication in this journal is cited, in accordance with accepted academic practice. No use, distribution or reproduction is permitted which does not comply with these terms. 